Periódico do Núcleo de Estudos e Pesquisas sobre Gênero e Direito Centro de Ciências Jurídicas - Universidade Federal da Paraíba

V. 8 - $\mathrm{N}^{\circ} 07$ - Ano 2019 - Special Edition ISSN | 2179-7137 | http://periodicos.ufpb.br/ojs2/index.php/ged/index

\title{
DIGITAL EVIDENCE IN JUDICIAL PRACTICE EVIDENCIA DIGITAL EN LA PRÁCTICA JUDICIAL
}

Guzel A. Valeeva ${ }^{1}$

Nikita N. Makolkin, ${ }^{2}$

\begin{abstract}
In this study, the authors consider digital evidence through the prism of implementing the idea of ejustice. The authors suggest that there is a need to regulate by law the rules for determining the admissibility and reliability of evidence, as well as to determine the range of possible actions and powers of the court and participants in the process when studying digital evidence.
\end{abstract}

Keywords: evidence, digital evidence, written evidence

\section{Introduction}

Administering law in the form of the civil, arbitration and administrative proceedings today involves the study of evidence, including digital, using advanced information technology for this purpose in the manner prescribed by law.

At the same time, both in legal doctrine and in law-enforcement practice, an aura of disputes and discussions arose around the legal nature and the very essence of digital evidence. It is important to note that in legislation, in periodicals, and in international practice there is no single concept describing the essence of this type of evidence. This state of affairs leads to the fact that the idea that they are separate and independent in a number of means of proof becomes more widespread, and, accordingly, the need for special legal regulation arises.

Taking into account the presence of this uncertainty, this work is aimed at studying how digital evidence is regulated in the jurisdictions of some states in the sphere of the judicial process.

\section{Methods}

\footnotetext{
${ }^{1}$ Faculty of Law, Kazan Federal University, Kazan, Russia, E-mail: GAValeeva@kpfu.ru

${ }^{2}$ Faculty of Law, Kazan Federal University, Kazan, Russia, e-mail: nikita.makolkin@gmail.com
} 


\section{Sirainere}

Periódico do Núcleo de Estudos e Pesquisas sobre Gênero e Direito Centro de Ciências Jurídicas - Universidade Federal da Paraíba

V. 8 - $\mathrm{N}^{\circ} 07$ - Ano 2019 - Special Edition ISSN | 2179-7137 | http://periodicos.ufpb.br/ojs2/index.php/ged/index

Comparative legal, deductive and inductive methods were chosen as the main tools for research of the issues under consideration.

\section{Results and discussion}

The rules for the use of digital evidence in the courts at the international level are somewhat incompletely regulated and vague, which makes it difficult to exchange information that affects the proof and enforcement of court orders.

Considering international legislation, it is necessary to mention the UN Convention on the Use of Electronic Communications in International Contracts dated November 23, 2005 [Mason and Rasmussen, 2016]. It was adopted by Russia in the Resolution of the Government of the Russian Federation on October 24, 2013, No. 940. It should be noted that this act does not include in its scope of regulation the contracts concluded for personal use and transactions in the regulated stock market. The main ideas of the Convention are the provisions aimed at regulating the effects of electronic contracts.
Of great interest among the acts regulating the activity in question, are acts of the European Parliament and the Council of the EU, which are declarative in nature: 1) Directive 1999/93 / EC dated December 13, 1999 "On the legal framework of the European Community for using digital signatures" [Manes, Downing, Watson., \& Thrutchley, 2007]; 2) Directive 2000/31 / EC dated 8.06.2000 "On e-commerce" [Kutsenko, 2016]. The main goal of these documents is the regulation of private law relations in correlation with the peculiarities of national law. Thus, specific requirements for the recognition of digital signatures are imposed on certification service providers, including the recovery of damages from them when they are issued to an indefinite number of persons and the revocation of qualified certificates of electronic digital signatures. At the same time, the courts are obliged to take into account the documents as evidence, even when there is doubt about the authenticity of a digital signature. The same state of affairs is due to the fact that the question of authenticity is to be established within a trial. 


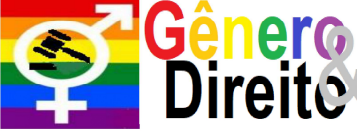

Periódico do Núcleo de Estudos e Pesquisas sobre Gênero e Direito

Centro de Ciências Jurídicas - Universidade Federal da Paraíba

V. 8 - $\mathrm{N}^{\circ} 07$ - Ano 2019 - Special Edition

ISSN | 2179-7137 | http://periodicos.ufpb.br/ojs2/index.php/ged/index

After more than 5 years, in 2016, the European Committee for Legal Cooperation conducted an international study on the introduction of digital evidence into the procedural laws of different countries. Respondents were asked 14 questions about the procedure for obtaining digital documents and the requirements established for such documents, etc. Also, the list included a question about the place of digital evidence within the system of evidence, as well as what evidence is considered reliable and whether other types are recognized as invalid. [Laevskaya, 2017] From the research it follows that digital evidence is often referred to as written (France, Italy, Germany, Latvia, etc.), while there are exceptions: for example, in England, Russia and Hungary it is possible to study digital evidence as to both written and physical evidence. The research results indicate that in a number of European states, with the presence of a special law on electronic documents, the relations in question remain insufficiently regulated in the procedural codes, which gives rise to negative phenomena in the
156

process of bringing judicial practice into uniformity.

At the same time, if we look at the overseas experience, it can be noted that in the United States since June 1, 1975, the rules of evidence established at the federal level are applied. These rules are currently being widely reformed through amendments affecting the standards for obtaining, processing and researching digital evidence in court proceedings. One of the latest amendments is to simplify the authentication of data obtained from electronic sources (dated December 1, 2017). Among other things, according to the provisions of the US Law on Digital signatures in World and National Trade, a digital signature can be an analogue of a handwritten signature, either a sound or a symbol, or any other action expressing the intention to sign an electronic document [Mason and Rasmussen, 2016].

In turn, in Canada, in addition to the Evidence Act, some courts form their own recommendations on the use of digital evidence in civil litigations [Manes, Downing, Watson., \& Thrutchley, 2007]. 


\section{Sirainere}

Periódico do Núcleo de Estudos e Pesquisas sobre Gênero e Direito Centro de Ciências Jurídicas - Universidade Federal da Paraíba V. 8 - $\mathrm{N}^{\circ} 07$ - Ano 2019 - Special Edition ISSN | 2179-7137 | http://periodicos.ufpb.br/ojs2/index.php/ged/index

The situation in the Russian Federation is similar; the issue of determining the procedural status of digital evidence in the system of evidence is quite acute. This leads to a number of problems:

1) The need for differentiating the sources of information obtained from digital evidence and electronic sources which are carriers of such information;

2) Identification of specific types of digital evidence affecting the procedure for their obtaining, providing, presenting, and researching them, including their authentication;

3) Optimization of the evidentiary rules included in the Code of Civil Procedure of the Russian Federation and the Arbitration Procedure Code of the Russian Federation regarding digital evidence.

Russian civil procedural legislation does not allocate digital evidence as a full-fledged means of evidence, nor does it applies and does not give a definition to the named term. At the same time, a number of regulatory legal acts contain a legal definition for an electronic document, which is presented by the legislator as information expressed in electronic form and transmitted via communication channels.

It is important to focus on the fact that the three procedural codes (Code of Civil Procedure of the Russian Federation, code of administrative court procedure of the Russian Federation and Arbitration Procedure Code of the Russian Federation) include digital evidence as written evidence with one difference: the Code of Civil Procedure of the Russian Federation and code of administrative court procedure of the Russian Federation speak of electronic documents and other materials executed in digital form and received using special technical means of communication, and in the Arbitration Procedure Code of the Russian Federation this list is narrowed down to electronic documents and other documents executed in this way.

Among other things, the Supreme Court of the Russian Federation in the Resolution of its Plenum speaks only of an electronic document and an electronic image of a document differing them from 


\section{Sirainere}

Periódico do Núcleo de Estudos e Pesquisas sobre Gênero e Direito

Centro de Ciências Jurídicas - Universidade Federal da Paraíba

V. 8 - $\mathrm{N}^{\circ} 07$ - Ano 2019 - Special Edition

ISSN | 2179-7137 | http://periodicos.ufpb.br/ojs2/index.php/ged/index

each other only in the method of their making. An electronic document is created in electronic form and signed with a digital signature, and an electronic image of a document is created by scanning the paper media and transferring it into electronic form.

Today, virtually everything can be electronic: documents, messages, correspondence, records of judicial and administrative bodies, technical information carriers, flash drives, Internet services, websites, archives, accounts, audio and video recordings, metadata, etc. At the same time, it would be incorrect to attribute all of them to one means of judicial proof being written evidence, or to unite judicial evidence into a separate group, calling it digital evidence. We believe that there is no need to deviate from the traditional division of evidence into types [Kutsenko, 2016] only on the basis of the special technical component of digital evidence. If, as a result of proving a specific fact, or group of facts, it is required to obtain information only about the production, quantitative and qualitative data of the corresponding
158

digital device or object of the information environment, then such digital evidence is real. If it is required to investigate and evaluate images, voice, movements, action (inaction), plot recorded on it using a digital device then this is nothing more than an audio or video recording. Digital evidence as written evidence should be considered taking into account all its information characteristics that express the thoughts and behavior of a particular subject of the relationship, as well as the material carrier of such information in order to establish its authentication and identification (i.e., obtaining additional information about the appearance of digital evidence, its modification, fixation and methods of transfer to other persons). In this regard, we consider it possible to disagree with the opinion of M.A. Mitrofanova that in this case only the information, regardless of its electronic carrier, has evidentiary value [Mitrofanova, 2013].

\section{Summary}

Written digital evidence can be of various kinds, but the most typical of them 


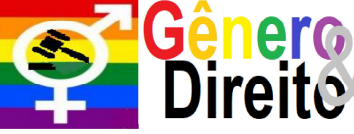

Periódico do Núcleo de Estudos e Pesquisas sobre Gênero e Direito

Centro de Ciências Jurídicas - Universidade Federal da Paraíba

V. 8 - $\mathrm{N}^{\circ} 07$ - Ano 2019 - Special Edition

ISSN | 2179-7137 | http://periodicos.ufpb.br/ojs2/index.php/ged/index

are electronic documents, messages and correspondence, screenshots of Internet sites and other sources of electronic information in the form of electronic images. In turn, all of them can be signed with a digital signature or not. Of course, the procedure for examining such evidence should be regulated by procedural law. Due to the lack of regulatory rules in judicial practice, especially arbitrage, where electronic circulation is most common, we have formed a number of conclusions. Pay attention to some of them:

1) The equivalence of an electronic document signed not only by an enhanced digital signature, but also by a simple or non-qualified digital signature, and a paper document signed by a handwritten signature, if the parties specifically stipulate this in an agreement or contract [Mitrofanova, 2013];

2) the use of digital signature by companies when signing an agreement is a direct proof of its conclusion, provided that the key certificate is valid at the time of signing the document [Bonner, 2013], while the burden of proving the invalidity
159

of the digital signature rests on the person denying the existence of disputable legal relations [Manes, Downing, Watson., \& Thrutchley, 2007];

3) electronic correspondence (communication) as written digital evidence is used by the parties quite often, but the courts are critical of this type of evidence if it is informal (it is believed that in this case, it is not legally relevant). Email addresses where official correspondence is sent should always be agreed upon by the parties. Otherwise, it is necessary to apply to a notary for inspection letters and attached files or to prove that the parties had a wellestablished practice of sending each other messages to the appropriate address or on the website there was set a publicly available controversial e-mail address. However, there is another approach, according to which the fact of labour relations with a plaintiff in a claim for confirmation of labour relations in the absence of a written employment contract can be confirmed by a set of circumstantial evidence and, in particular, by electronic correspondence and SMS messages. 


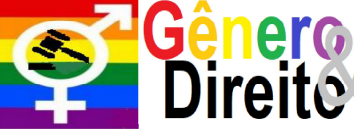

Periódico do Núcleo de Estudos e Pesquisas sobre Gênero e Direito Centro de Ciências Jurídicas - Universidade Federal da Paraíba V. 8 - $\mathrm{N}^{\circ} 07$ - Ano 2019 - Special Edition ISSN | 2179-7137 | http://periodicos.ufpb.br/ojs2/index.php/ged/index

Moreover, the addresses do not have to be agreed, since an employee is the weak side of labour relationships [Mitrofanova, 2013];

4) Screenshots of sites are not always recognized as adequate evidence for several reasons: the site address, the date of receiving the screenshot, the authorized person's signature, and a party has the technical ability to change the content, are not indicated [Mason and Rasmussen, 2016];

5) Sending of confidential information by a responsible person to a personal e-mail (or other mail) is assessed by the courts as its disclosure to third parties [Laevskaya, 2017].

The above findings of judicial practice deserve the attention of the legislator and contribute to the further conceptual development of the institution of judicial evidence.

\section{Conclusions}

The development of e-justice in Russia is taking on a wide scale; therefore, a comprehensive and integrated approach is needed to study not so many common
160

concepts and global perspectives as elementary but significant institutions, without which procedural actions would be difficult. In particular, we believe that the widespread use of digital evidence in court proceedings will inevitably and in the near future become a key element of the entire legal process. Obviously, there are not enough valid standards. Digital evidence as a form of written physical evidence or audio and video recordings should not be vulnerable; on the contrary, their presence in the case should serve as a guarantor of the court making a correct and lawful decision.

\section{References}

Mason S., Rasmussen U. (2016). The Use of Electronic Evidence in Civil and Administrative Law Proceedings and Its Effect on the Rules of Evidence and Modes of Proof. Strasbourg, 27 July 2016 CDCJ(2015)14 // - URL: https://rm.coe.int/1680700298. 
Manes, G. W., Downing, E., Watson, L., \& Thrutchley, C. (2007). New federal rules and digital evidence.

Kutsenko T. M. (2016). New types of documents and material evidence in the proceedings for administrative offences: problems of theory and legal regulation in the Russian Federation: the dissertation of the Candidate of Legal Sciences. SPb., 2016. P. 89.

Laevskaya A.V. (2017). Digital evidence in the civil and economic process of the Republic of Belarus: Extended abstract of Candidate of legal sciences dissertation. Minsk, 2017. P. 4.

Bonner A.T. (2013). Traditional and nontraditional means of evidence in civil and arbitration proceedings: Monograph. M.: Prospect, 2013. P. 340 - 544.

Mitrofanova M.A. (2013). Digital evidence and the principle of immediacy in the arbitration process: Extended abstract of Candidate of legal sciences dissertation. Saratov, 2013. P. 13. 